International Crisis Group

Founded 1995. Independent, non-profit organization committed to preventing and resolving deadly conflict. Combines field-based analysis, policy advice and high-level advocacy to highlight potential future conflicts, resolve peace negotiations and advise governments and intergovernmental bodies.

Address: 149 avenue Louise, Level 24, B-1050 Brussels, Belgium. Website: http://www.crisisgroup.org

President: Louise Arbour.

\section{International Institute for Strategic Studies (IISS)}

Founded 1958. Independent organization, considered the world's leading authority on political-military conflict. Research programme themes: conflict; defence and military analysis; economics and conflict resolution; non-proliferation and disarmament; transnational threats and international political risk; transatlantic dialogue on climate change and security.

Address: Arundel House, 13-15 Arundel St., Temple Place, London WC2R 3DX, UK.

Website: http://www.iiss.org

Director-General: Dr John Chipman.

\section{Japan Institute of International Affairs (JIIA)}

Founded 1959. Private, non-partisan institute committed to research on foreign affairs and security issues. Examines Japanese foreign policy, provides policy recommendations to the government and disseminates information on international relations to the public. JIIA aims to serve as an indispensable resource on international affairs.

Address: 3rd Floor Toranomon Mitsui Building, 3-8-1

Kasumigaseki, Chiyodaku, Tokyo 100-0013, Japan.

Website: http://www2.jiia.or.jp

President: Yoshiji Nogami.

\section{Kiel Institute for the World Economy (Institut für Weltwirtschaft an der Universität Kiel; IfW)}

Founded 1914. Independent, international centre for research in global economic affairs, economic policy consulting, economic education and documentation. Research areas: the global division of labour; knowledge creation and growth; the environment and natural resources; poverty reduction, equity and development; monetary policy under market imperfections; financial markets and macroeconomic activity; reforming the welfare society.

Address: Hindenburgufer 66, 24105 Kiel, Germany.

Website: http://www.ifw-kiel.de

President: Prof. Dennis Snower.

\section{Konrad Adenauer Foundation (Konrad-Adenauer-Stiftung)}

Founded in 1955 as the Society for Christian Democratic Civic Education and renamed in 1964. Political foundation that focuses on consolidating democracy, the unification of Europe and the strengthening of transatlantic relations, as well as on development co-operation.

Address: Klingelhöferstrasse 23, 10785 Berlin, Germany;

Rathausallee 12, 53757 Sankt Augustin, Germany.

Website: http://www.kas.de

Chairman: Dr Hans-Gert Pöttering.

\section{Korea Development Institute (KDI)}

Founded 1971. Think tank set up by the government aiming to make substantial contributions to the economic and social development of Korea. Research focuses on providing policy recommendations and guidance based on in-depth analyses of international and domestic economic conditions and projections.

Address: Hoegiro 47, Dongdaemun-gu, Seoul, 130-740,

South Korea.

Website: http://www.kdi.re.kr

President: Kim Joon-kyung.

\section{Lowy Institute for International Policy}

Founded 2003. Independent think tank that seeks to generate new ideas and dialogue on international developments and Australia's role in the world. Research ranges across all the dimensions of international policy debate in Australia-economic, political and strategic-and is not limited to a particular geographic region.

Address: 31 Bligh St., Sydney, NSW 2000, Australia.

Website: http://www.lowyinstitute.org

Executive Director: Michael Fullilove.

\section{National Bureau of Economic Research (NBER)}

Founded 1920. Private, non-profit, non-partisan research organization dedicated to promoting a greater understanding of how the economy works. Concentrates on four types of empirical research: developing new statistical measurements, estimating quantitative models of economic behaviour, assessing the economic effects of public policies and projecting the effects of alternative policy proposals.

Address: 1050 Massachusetts Ave., Cambridge, Massachusetts 02138-5398, USA.

Website: http://www.nber.org

President: James Poterba.

\section{Netherlands Institute of International Relations 'Clingendael'}

Non-profit, independent think tank for international relations. Identifies and analyses emerging political and social developments for the benefit of government and the general public. Programme concentrations: diplomatic studies; European studies; security and conflict; international energy.

Address: Clingendael 7, 2597 VH The Hague, Netherlands.

Website: http://www.clingendael.nl

Director: Ron Ton.

\section{Overseas Development Institute}

Founded 1960. Independent think tank that focuses on international development and humanitarian issues. It aims to inform policy and practice that lead to the reduction of poverty, the alleviation of suffering and the achievement of sustainable livelihoods in developing countries.

Address: 203 Blackfriars Road, London SE1 8NJ, UK.

Website: http://www.odi.org.uk

Director: Alison Evans. 